\title{
THE CHARACTER OF BUILDING APPEARANCE OF THE MONUMENT HELAL IBN IBN ALI (AS) THROUGH COMPARISON OF TRADITIONAL AND CONTEMPORARY BUILDINGS OF ARAN AND BIDGOL BASED ON QUALITATIVE INDICATORS OF DE BATTON
}

\author{
Ahmad Danaeinia \\ Assistant Professor, Department of Design and Art, University of Kashan, Kashan, Iran \\ Habibalah Pourebrahimi Arany \\ Architecture graduate student, Department of Design and Art, University of Kashan, Kashan, Iran \\ poorebrahimi.h177@yahoo.com
}

\begin{abstract}
Ignorance of the dignity of holy shrines in the design and provision of infill projects on one of the most important religious buildings, the tombs of saints and solving design problems through visual elements or techniques which are not in common with application subject led to users' behavior and communication is reduced to a minimum. This article focuses on the tomb shrine of Helal bin Ali (AS) in Aran and some other traditional buildings and comparative comparison with some contemporary buildings in the same city is trying to analyze the factors affecting the visual character of the buildings. The study is a correlation one and gathering information has been done through library studies, field studies and observation. Explanation has been done as analog and analysis of the results in the comparative figures have been derived from the proposed model of Rappaport. In this respect, indicators of happiness, luxury, readability and meaning were measured based on votes De batton and for four species of architecture two groups of traditional and contemporary buildings have been studied. The results of the comparison charts of happiness and luxury of traditional buildings, suggests the superiority of six points of Helal bin Ali (AS) tomb shrine compared with the average of other three buildings; which this positive difference, compared to the average contemporary buildings has been four and four and a half, respectively. This superiority in readability and meaning indicators in comparison with traditional and contemporary buildings has been four and four and a half, respectively. The results of the study indicate that due to respect of quality indices raised, the relative richness of the architectural monument of shrine Helal bin Ali (AS) is premium, and sense of belonging to place has been preserved among the pilgrims and adjacent.
\end{abstract}

Keywords: Aran and Bidgol, Monument of Helal Ibn Ali (AS), character, quality indicators of De batton

\section{INTRODUCTION}

Not only in Iranian-Islamic culture, but in all human societies, with any culture and infrastructure of any faith, always individuals status has been took special attention. Obviously, the status largely is provided through presence in the architectural space. Wherever architecture appears consistent with human dignity will be resulted in an appropriate response; and in the case of rash design; will have undesirable results. Sometimes even the expression of social status through outward shape and exterior appearance of the house or place alleged to person occur. Neighborhoods and urban spaces express social status as well. So, the view and even the type of plant and organizing them in front of gardens, is widely used in many areas to express dignity (status). The bars and other components also are examples of such. Therefore, one of the key architectural role is foundation to dignity (status) and protect it, whether for human or building.

According to De batton, architecture carries ethical message, that instead of imposing, inviting people to its side. We have been trying to establish a kind of unity between mind and our inner world and peripheral visual world and associative thinking contribute to this important. So, we consider something beautiful; that fits with our mental values and make us pleased and happy. Thus, it may be concluded; the beauty is the same joy (4). To measure the aforementioned unity, happiness and luxury index include: decorations, colors, attention to detail, materials, elements of nature, as well as readability and significant indices includes: 
symbol, sign and dreamy, discipline and simplicity, diagnosis and shaft sealing, glory of scale, lighting and shadow and light, seem appropriate. These characteristics may be the category of beauty or glory.

Although a wide variety of means to establish and maintain the dignity of the building, but in this study to focus more on two important and comprehensive indices of $<<$ luxury and beauty $>>$ and $<<$ readability and meaning $>>$ based on findings, from Alain de Botton views are produced and for four groups of character, two groups of traditional buildings have been selected as assessment criterion.

\section{PROBLEM STATEMENT AND NECESSITY OF TOPIC}

Readability and meaning are two important indicators; that have significant impact in viewer's understanding of the architectural space. Also happiness and luxury are two other factors of building which are involved in creating different moods in people. This article concerned with is the ignoring of the dignity differences of various buildings and as a result solving design problems with tools, visual techniques or elements; with no common aspect with the building's application and in addition to wrong understanding of the building, does not meet necessary and according to need visual feel. People's different behavior in different situations, greatly influenced by the designed environment or on the other words the architectural space. Also, lack of sufficient knowledge of the character of the various groups has led to what is expected, not to be realized in terms of performance of a building. Improper use of architectural elements and concepts, led to deterioration in the human behavior and communication with the building and thus denying the norms. This increases the responsibility of architects and designers and they obliged to study and take effective measures. Therefore, such a research seems necessary.

\section{RESEARCH OBJECTIVES}

1. To identify and enhance the design parameters in the tombs of saints

2. The promotion of religious tourism by strengthening indicators of quality in architectural design.

\section{RESEARCH QUESTIONS}

1. Contemporary and traditional buildings of Aran and Bidgol have what level of happiness and luxury and readability and significantly compared each other?

2. How is the appearance status (dignity) of the building of monument shrine Helal Ibn Ali (AS) as a traditional building of cultural-religious group compared other traditional and contemporary groups within the outlined parameters?

\section{RESEARCH HYPOTHESIS}

- $\quad$ It seems the order in the indices of happiness and luxury (A) as follows:

$2<4<1<3$

It seems the order in the indices of meaning and readability (B) as follows:

\section{$4<3<2<1$}

It seems the appearance of the building of monument shrine Helal Ibn Ali (AS) compared different traditional and contemporary buildings groups has a good position (status), because before any scientific study, presence in the complex is accompanied by a feeling of mental freshness and a kind of humbleness by people to that.

\section{RESEARCH METHOD}

The study is a correlation one and gathering information has been done through library studies, field studies and observation. In this respect, indicators of happiness, luxury, readability and meaning were measured based on votes De batton and for four specified buildings various character spices including: culturalreligious monuments, political and governance structures, economic, recreational and residential buildings and municipal services buildings from two groups of traditional and contemporary buildings has been examined. The mechanisms of people's communication with environment from Amos Rapoport's views were basis of assessment. Also, comparative explanation was used to analysis of results obtained in comparative charts derived from his proposed model. Then the logical reasoning of achievements from graphs and tables led to the obtained results. 


\section{COMMUNICATION PATTERNS OF PEOPLE AND THE ENVIRONMENT}

These patterns, by which people understand space and compare the character to its dignity, include (3):

1. Physical condition: adaptability and comfort with respect to temperature, humidity, brightness and...

2. Anatomy: The size and height of components.

3. Perception: The most important mechanism, is receiving sensory information from the environment

4. Knowing (cognition): it is related to mental processes that involve between the perception (of information) and knowledge of the environment

5. Meaning: it is related anthropological aspects of knowledge, reflecting the hidden and very important aspects and involves images, ideals and social status, identity and many aspects of environment

6. Effects: the sensation and mood concluded by the environment

7. Assessment: it is led to priorities and choices most often based on demands (and in connection with the meaning and consequence) rather the needs

8. Activity and behavior: reply to understand, meaning, work (effect) and evaluation

9. Sponsorship: it can be physiology, anatomy, psychology and so on

10. Expectations, norms, standards and rules: values, images and ...for certain expectations and as a result lead to norms, standards and laws

\section{MEASURES OF ASSESSMENT}

A- Happiness and luxury indices include:

Decorations + color + attention to details + materials + nature

B- Readability and semantic index include:

Symbol, sign and fancy + discipline + diagnostics and $\ldots+$ glory of scale + lighting and shadow and light in day

Formula: $(-2$ to +2$)+(-2$ to +2$)+(-2$ to +2$)+(-2$ to +2$)+(-2$ to +2$)$

\section{FOUR CHARACTER TYPES}

Types 1: socio-cultural monuments, cultural-religious monuments, academic buildings

Socio-cultural monuments include: the cultural center, museum, seminary school and ...

Religious-cultural monuments, including: mosques, Mosalla, religious site, tomb and...

Scientific monuments include: university, school and...

Type 2: Political and government buildings, monuments of criminal and law, regulatory and legal structures

Political and governance structures, including: the governors, governors, ministries, county and...

Law and crime structures, including: the judiciary, police, courts, prisons, conflict resolution and...

Regulatory and legal structures include: traffic, public monitoring, engineering organization, medical systems

Type 3: economic, recreational and residential buildings

Economic monuments, including: banks, businesses, shops and ...

Recreational buildings, including hotels, gardens, Game Center, restaurants, gyms, swimming pools and...

Type 4: urban utilities buildings, health care buildings 
Monuments utilities include: post, telecommunications, municipal

Urban utilities buildings, including hospitals, pharmacies, clinics and...

The introduction of traditional buildings to analyze on the basis of De Batton indexes

Traditional building of type 1: Shrine tomb of Helal Ibn Ali (AS)

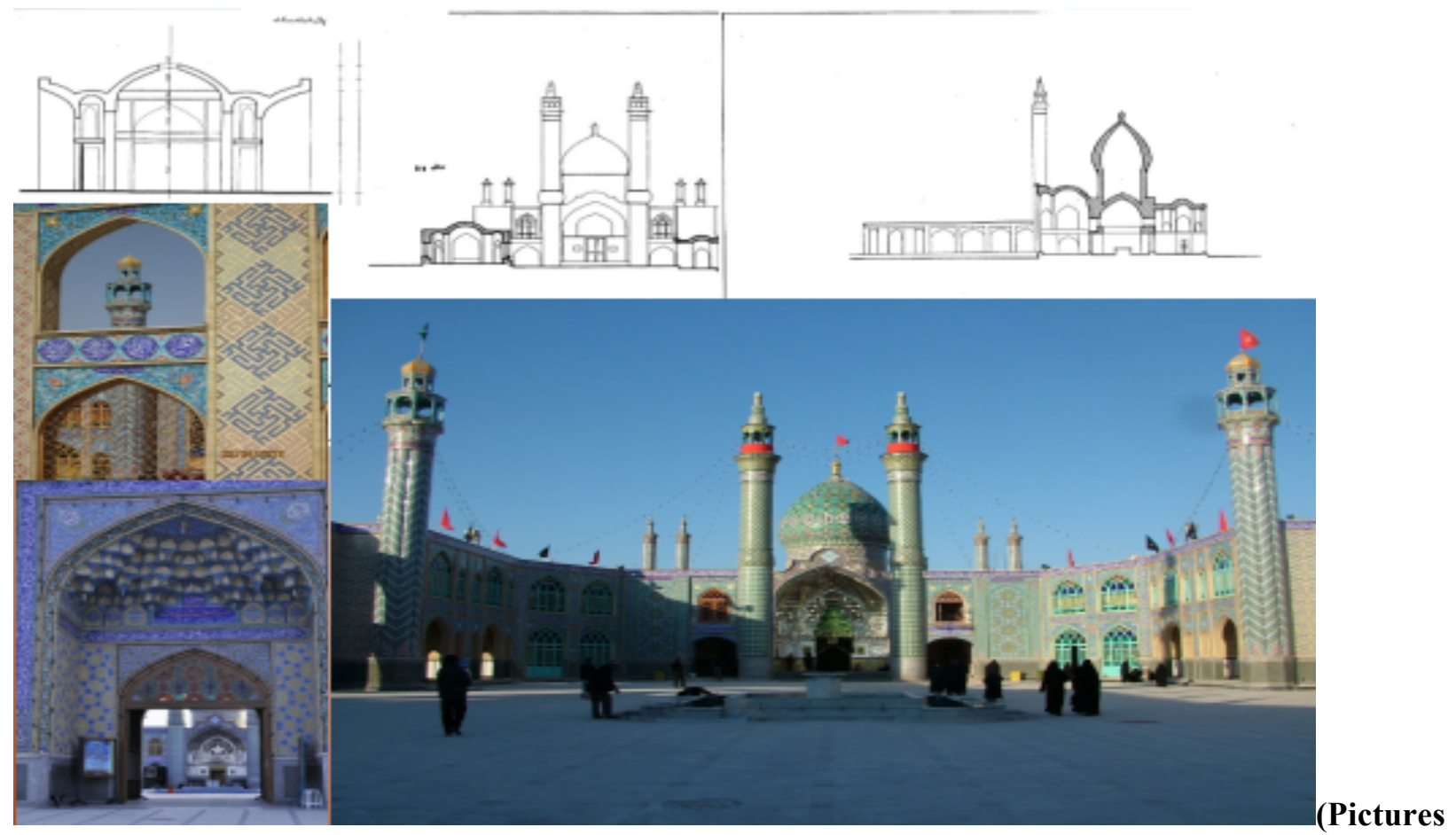

from the author) (Map: Center for documents of Cultural Heritage Administration of Aran and Bidgol)

Mohammad Osat nicknamed Helal, known as Mohammed Hilal Ibn Ali (AS) and his noble mother, Amameh, Zainab's Daughter, is child of the Messenger of Allah (PBUH). His exile, has been after the Ashura event in $61 \mathrm{AH}$ [Anno Hegirae] and from Taif to Tus, Qom and Aran. He was hosted by Jacob in Aran for three years; and on Friday night last ten days of Ramadan of 64 AH joined to his holy ancestors (peace be upon them). The building of honorable's tomb dates back to the Safavid era and Shrine roof and mirror work has been done on a vow and ordered by Karim Khan Zand.

\section{TRADITIONAL BUILDING OF TYPE 2: MINISTER'S CASTLE}

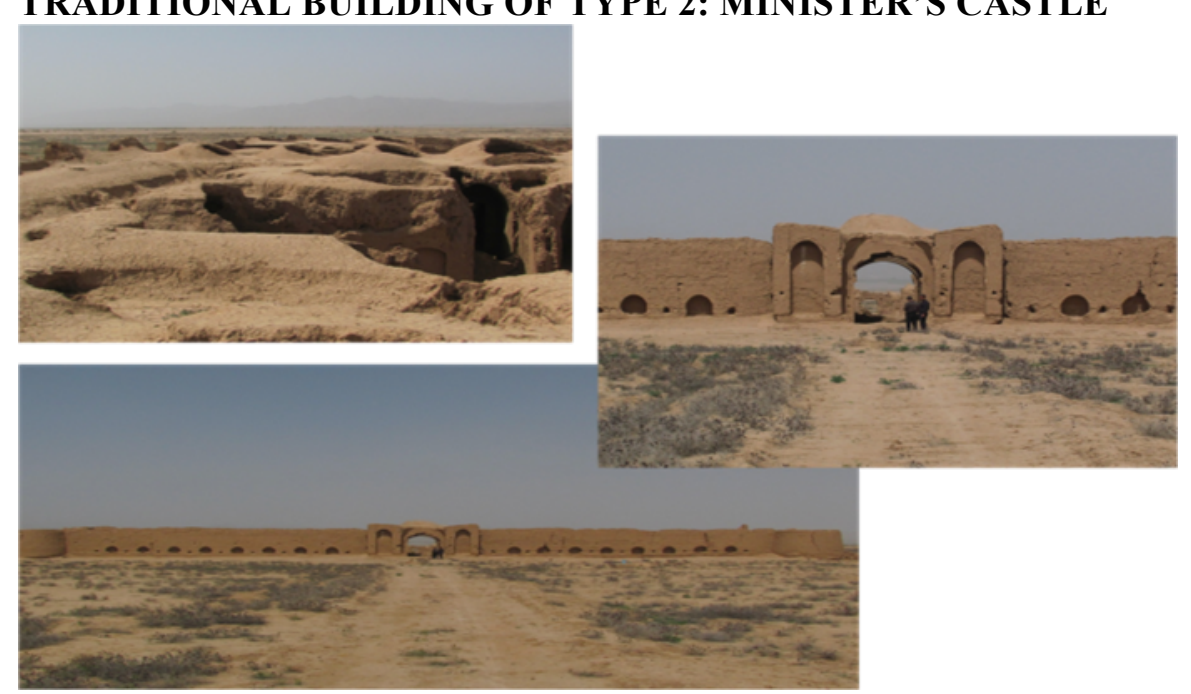


(Picture from the author)

This castle has survived within the north part of the White City (Sefid-Shahr) of central part of Aran and Bidgol with the military use of historical monuments.

\section{TRADITIONAL BUILDING OF TYPE 3: MARANJAB INN}
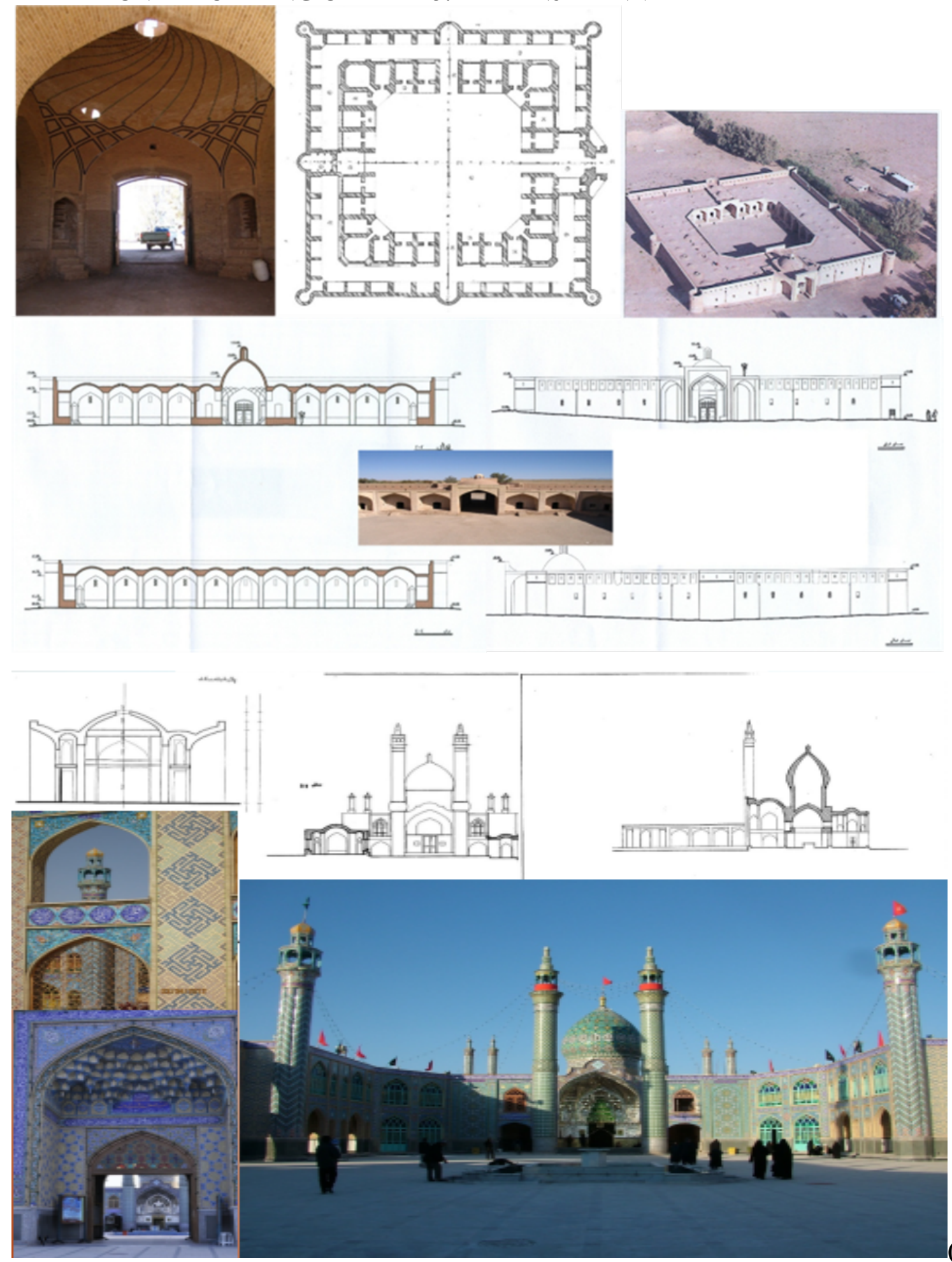

from the author) (Map: Center for documents of Cultural Heritage Administration of Aran and Bidgol)

This inn (Caravanserai) is located on the Silk Road and with respect to the nature and the arid climate of Maranjab, has introverted architecture. This monument has a central courtyard and of four porches type. This 
building consists of entrance and vestibule (narthex) entrance, four Porches, cells with front entrance of porch, around the courtyard and stables and is four towers at the four corners.

\section{TRADITIONAL BUILDING OF TYPE 4: HISTORICAL ĀB ANBĀR OR WATER RESERVOIR (FRIDGE CORNER)}

(Pictures from the author)

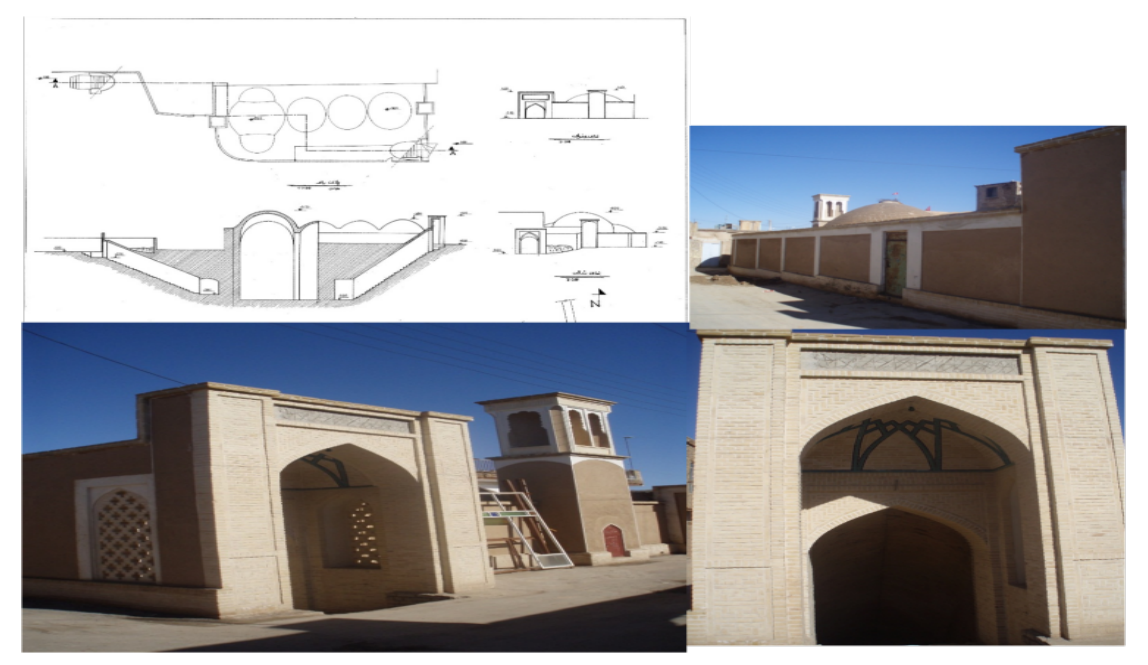

This āb anbār or water reservoir currently has two input doors. Dating back to the Qajar; and access to main entrance and old Pashyr [the standing in cellar where water is provided] with 31 stairs to a height of 27 $\mathrm{cm}$, and for new entrance Pashyr with 32 stairs to a height of $20 \mathrm{~cm}$ is possible. Entry level difference to the bottom of the water tank is about 8.5 meters. Ab anbār or water reservoir also has two windward which have been located on both sides of the rectangular water tank. The roof (top) of water tank is four-piece and dome-shaped. The old entrance has an inscription with polychrome tiles, containing Do-bayti (in Persian, a poetry style). According to the ancients one Pashyr has been for men and one for women.

The introduction of contemporary buildings to analysis based on De batton's indices

The contemporary building of type 1: Tomb of Suleiman Sabahi Bidgoli

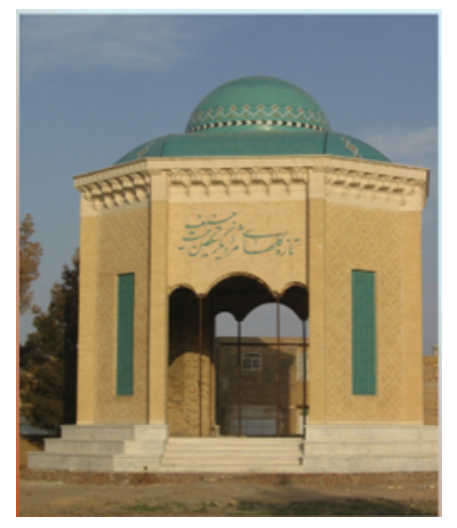

Haj Suleiman Sabahi Bidgoli, of famous poets and literary movement founders called return. He died in the early reign of Fath Ali Shah Qajar dynasty (13th century AD). This great poet's tomb located in the vicinity of Imam Hussein, in the quarter of Darb-e Rig (gritty door) of Bidgol.

Do-bayti (in Persian, a poetry style)

My homeland is Bidgol but no one has seen the dawn

In the hand of flower, or on the crown of my willow shade

(Pictures from the author) 


\section{CONTEMPORARY (MODERN) BUILDINGS OF TYPE 2: GOVERNOR BUILDING OF ARAN} AND BIDGOL

Aran and Bidgol, is northernmost city of the Isfahan province which new Governor building of it was inaugurated in 2009.

(Pictures from the author)

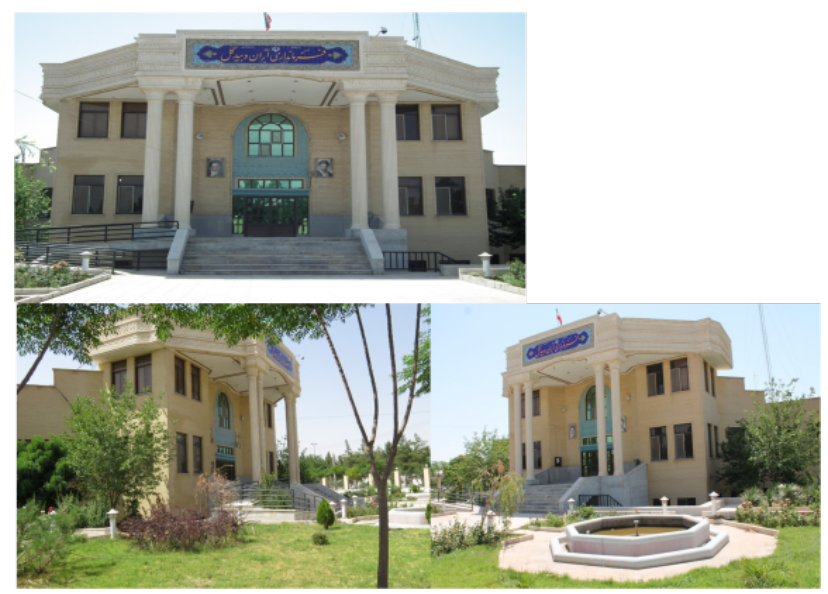

\section{CONTEMPORARY (MODERN) BUILDING OF TYPE 3: COMMERCIAL COMPLEX OF} SHABAN

This building located in Sepah square of Aran and Bidgol includes a variety of shops, business offices, offices and clinics.

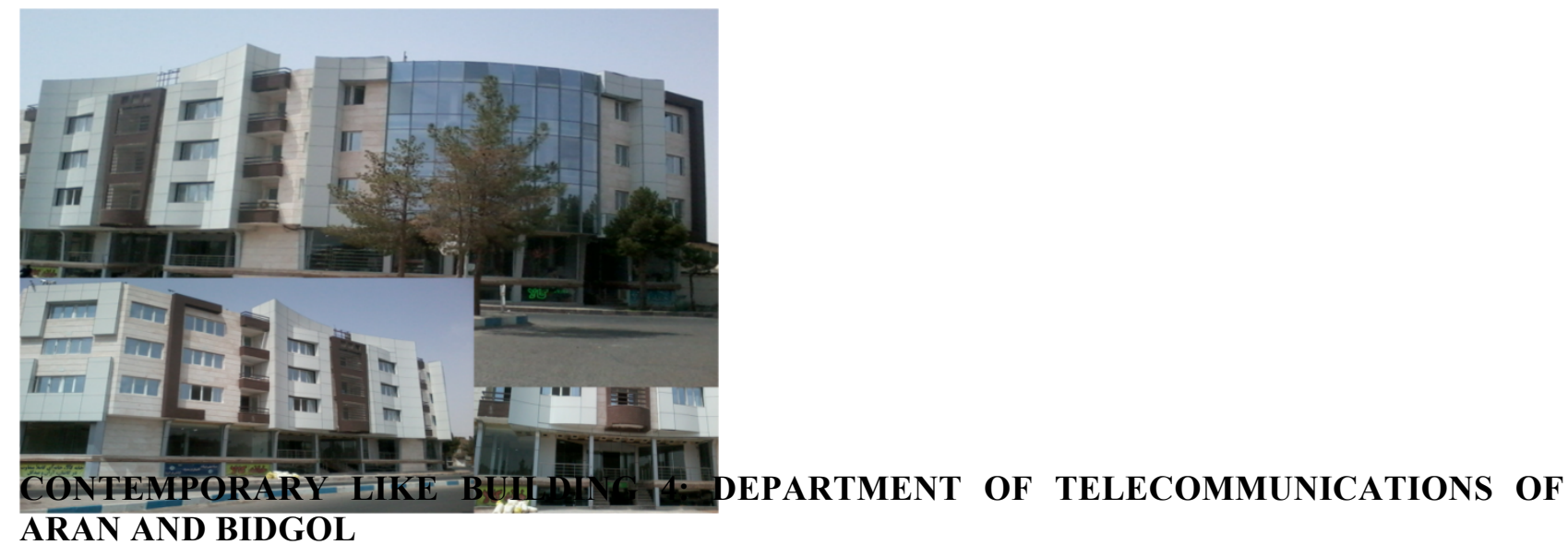
ARAN AND BIDGOL

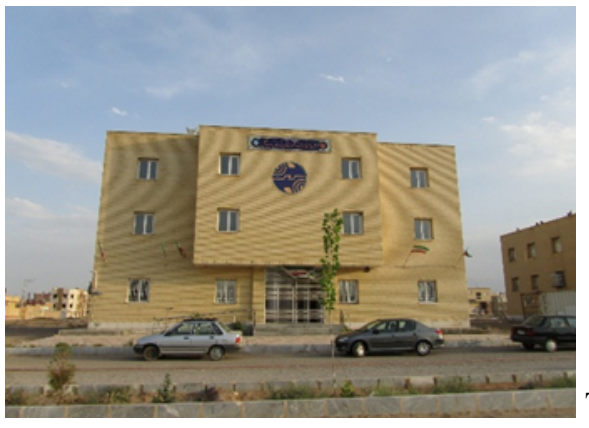

This building was put into operation in 2012

Analysis of traditional buildings in luxury and happiness index 


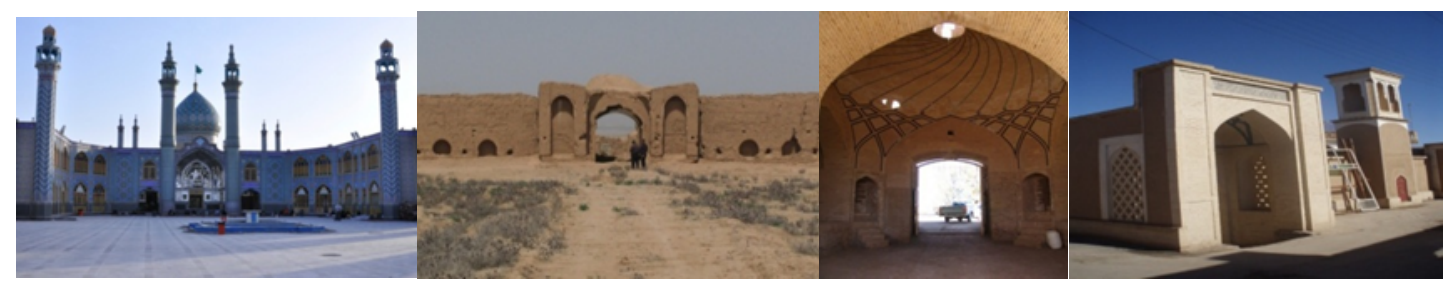

1-Monument of Imam-zadeh Helal (AS)

2. Minister's Castle

3- Maranjab inn (carvan sara)

4- The corner $\mathrm{Ab}$ anbār or water reservoir

\section{ORNAMENTS}

Type 1- The ornaments are maximal in the body wall and the dome and are minimal in the windows and doors. Ornaments are in the form of arches, geometric shapes, nodes, etc. and in Tiling [Kashi Kari] and mirror work [Ayneh Kari].

Type 2-There's little information about ornaments and is limited to a few semi-circular arch arcades on the walls.

Type 3-Pointed arches, Rasmi bani (in Iranian-Islamic architecture), Ma'aqly with pinwheel design and a bit of bricklayer decorating has got the necessary liveliness to facades.

Type 4- Pointed and decorative arches, a bricklayer, a network of Jafari, snap brick, thatch and Karbandi (In Iranian-Islamic architecture), each of them have been applied shortly and in brief.

\section{COLOR}

Type 1-The total area has been covered by exterior turquoise blue, but the color variation is evident as well.

Type 2-Uniformity in color and exclusivity to the gray and avoidance from variations in coloring is at minimum.

Type 3-In the background of brick color of entrance, one or two colors cautiously and selectively have been used.

Type 4-The facade is limited to a few colors of brick, chocolate Simgel (mortar of plaster and mud), white and a little blue.

\section{ATTENTION TO DETAILS}

Type 1-In the dome, finial, body and forehead and the porch centimeter accurate has been considered, but the stone plinth and windows are exception.

Type 2-All the visual elements of building are general and detailed levels has not been undefined at all and.

Type 3-Despite the simplicity of the facade, details deliberately especially in the Karbandi and bricklayer has been considered.

Type 4- It is different at various levels. In the Simgel (mortar of plaster and mud) and bricklaying less and in decorative plaster arcs and in Jafari network is more.

\section{MATERIALS}

Type 1-Body tile, plinth stone and mirrors on the porch are the main used materials, but with different ratios induce happiness.

Type 2-Is limited to clay, which has the most positive effects on humans.

Type 3-Baked brick and a bit of glazed tile which raw materials in both is clay, involved with its positive energy. 
Type 4-The right combination of brick and thatch with a lot of positive energy and gypsum has added to the charm and vitality of building.

\section{NATURE}

Type 1-In the view of the front of building, green nature does not exist, but blue sky or dispersed clouds and finial create a nice combination and waterfront is basis for important natural element of water.

Type 2- Considering the location of the building, its share of the nature is limited to the sky and barren desert.

Type 3-Given being in the desert, its share of nature, is the picture of sand dunes adjacent to the building and the sky above.

Type 4- Apart from the skies above the building, only the design of Jafari networks (grids) rooted in nature.

\section{ANALYSIS OF TRADITIONAL BUILDINGS IN READABILITY AND MEANING INDICES}

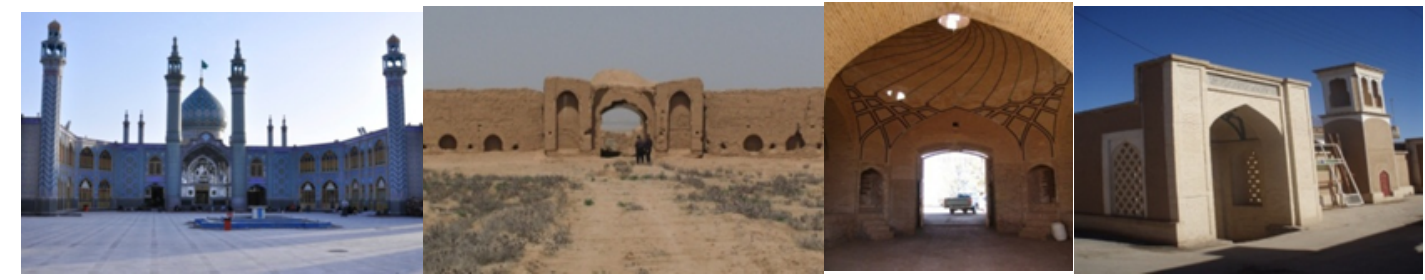

1-Monument of Imam-zadeh Helal (AS)

2. Minister's Castle

3- Maranjab inn (carvan sara)

4- The corner $\mathrm{Ab}$ anbār or water reservoir

\section{SYMBOL, SIGN, AND FANCY}

Type 1-The finials to the sky, evokes need hands to the Creator, and also spiritual growth to infinite. Skyline with immersed elements at twilight and dawn nature, give fancy pictures to the viewer.

Type 2- The combination of input elements and its volume emphasize the power lied in the building. Its shape particularly the two sides arch-shaped, with angle in top horizontal lines, associate the dynamism and readiness to offensive or defensive referring its military use well.

Type 3-The outer elements of building evokes a kind of lightness and freshness with a sense of security that is required in inn.

Type 4- The visage of building review an image of earth deep to top of sky for the viewer. Ab anbar (water reservoir) stairs and its roof downward show us the most precious source of life and the windward shows us the infinite power.

\section{ORDER AND SIMPLICITY}

Type 1- The arrangement of elements is irregular. Although is not simple and associated with significant variation.

Type 2- Arcades repeat on both sides of the wall suggests the order of the building. Aside from the arc used, the simplicity is its peak.

Type 3-Members beside partial diversity regularly and properly are located in their place.

Type 4-The arrangement of elements has no certain order, and continuity of simplicity is too low.

\section{INDIVIDUATION AND AXIS}

Type 1-The facade to the vertical axis has perfect symmetry and if two small finials on the sides did not exist, the individuation of main theme seemed more complete.

Type 2-The building to the vertical axis has symmetry; the individuation is maximal. 
Type 3- The building to the vertical axis has symmetry; but the rough equality of entry height, and the rest of the body has reduced its individuation.

Type 4-Each member of has separately symmetry to vertical axis alone, but the building in total doesn't have the symmetry. Therefore, the individuation can't be ascertained, as well.

\section{GLORY OF SCALE}

Type 1-The building to human scale and the around monuments has glory of a sacred edifice.

Type 2-As qualified for building's use, has the grandeur and glory of scale to the human dimensions.

Type 3-Unlike buildings of this group, Maranjab inn due to placement in the desert has been performed with a larger scale to beside the provision of introspection provide the necessary security and peace.

Type 4-The ab anbar (water reservoir) can be investigated in human scale. But windward due to unique application (use) has dimensions beyond it. Totally man does not feel humiliation in front of the building.

\section{SHADOW AND LIGHT (PENUMBRA)}

Type 1-Windows are not indented, but the prospect of three fronts simultaneously, creating a beautiful shadow and light (Penumbra) and movement. Also porch and two side entrances and the dome and finials volume, gives people the opportunity to watch play with a beautiful light.

Type 2- Is limited to indent of arcades.

Type 3-The protrusion of entrance vestibule to the rest of the body, creates Shadow and light (Penumbra); the rest of the body is uniform. Only the rectangular towers add a small to this feature.

Type 4-Shading and play with light and shadow in building than its size is maximal. The today's technology in electricity has spread this soft into the night.

\section{THE COMPARISON OF CONTEMPORARY BUILDINGS IN LUXURY AND HAPPINESS INDICES}

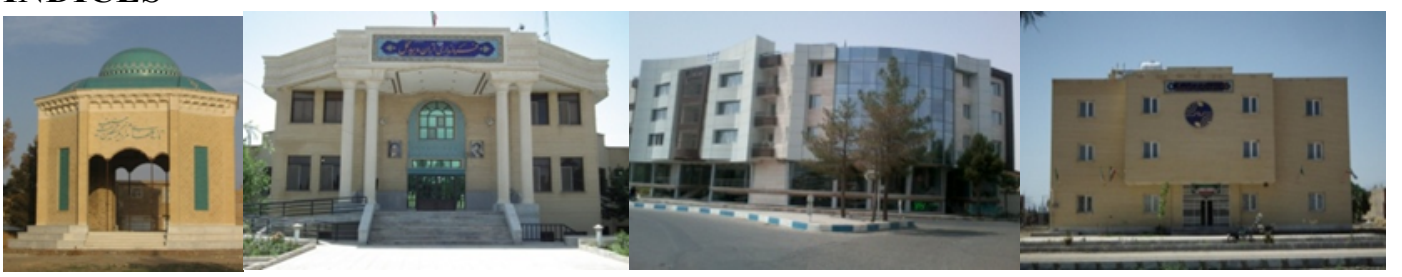

Type 1-Tomb of Suleiman Sabahi

Type 2-Governor building

Type 3- Shaban complex

Type 4-Department of Telecommunications

\section{ORNAMENTS}

Type 1- Unmixed tile, with simple strips in the dome, Gilloyee (The distance between the ceiling and the wall) by repeating semi-formal work design, exist in the head of the body, bricklaying, tile and decorative arches.

Type 2- Limited to capitals and cement stripes, eaves of ceiling and arch of window top of the entrance.

Type 3- In the conventional sense is not seen except under the entrance roof, but building has been decorated with various thematic structure and different designs, of course simple.

Type 4- There are no ornaments (decorations) and building name in a small frame, has a brief word to say.

\section{COLOR}

Type 1- The turquoise blue dome in combination with white and dark, on the ocher, cream and turquoise facade are among characteristics of this building. 
Type 2-A combination of white, brick, blue, brown, gray, are variety set of pretty cool colors on the facade.

Type 3- A combination of white, brick, blue, brown, gray, are variety set of pretty cool colors on the facade.

Type 4- Only one brick color has been used in facade, and only the logo and the name of building has different colored spots.

\section{ATTENTION TO DETAILS}

Type 1-At all levels except the stairs and stair elements of building base, detail has been carefully considered.

Type 2-The constituent elements generally are introduced, and except a few in forehead ornamentation, in the rest of levels the details have not been addressed.

Type 3-Details role in the introduction of the building is very pale. But on a larger scale each level has different details.

Type 4-Attention to detail is minimal

\section{MATERIALS}

Type 1-Tile, concrete (cement), brick, and stone, are the material of dome and body, a perfect combination to induce happiness and dignity in the same.

Type 2-Cement, tile, brick and stone have created a cold and serious combination.

Type 3-Materials of composite facade of glass, aluminum sheet, stone and a few brick have a high percentage of happiness.

Type 4- Monopoly of materials to brick only, has minimized the attraction of the building.

\section{NATURE}

Type 1- Above sky and a number of trees in the vicinity of the building, are the only symbols of nature.

Type 2-Green space around the building, and with greater accuracy in the frame of the building name, the ivy sidelines are symbols of nature.

Type 3-Urban green space and trees of the square, around the building, are the share of building from nature.

Type 4-Now the nature share in the building is negligible.

\section{THE COMPARISON OF CONTEMPORARY BUILDINGS IN READABILITY AND MEANING INDICES}

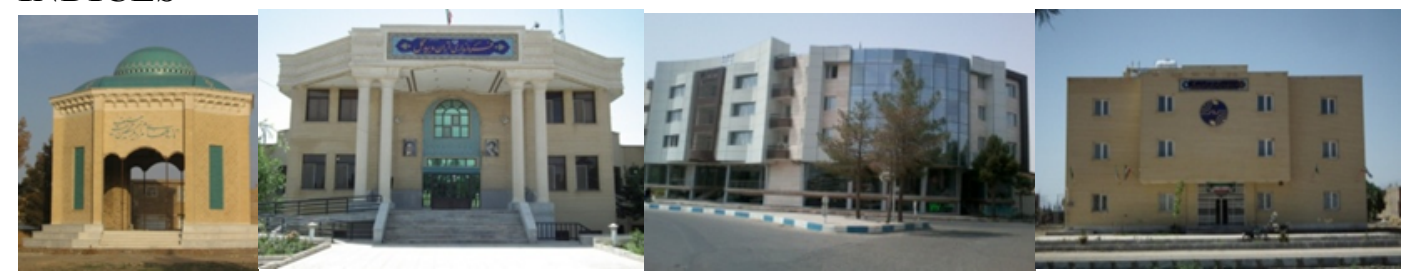

Type 1-Tomb of Suleiman Sabahi

Type 2-Governor building

Type 3- Shaban complex

Type 4-Department of Telecommunications

\section{SYMBOL, SIGN, AND FANCY}

Type 1-Although it has been tried with diversity the materials and design, create a proportionate to the tomb of the famous poet, but visual weight still dominant in the building. Only the image of a hemistich of poems with a beautiful line of Nastaliq helps to poetry space. 
Type 2-The columns of even-numbered entrance side, with the Doric order capitals and ornaments inspired by the architecture of Rome and Greece in the forehead of building shows it in a position of power, and concise tiles can't be used to compensate for it.

Type 3- Signs of forgot of climate and architectural identity of the city can be seen in this building, but fancy in it has more strength.

Type 4- The building view reflects fully machined and performance mood and, and without any emotion continues its life.

\section{ORDER AND SIMPLICITY}

Type 1-The building in addition to the diversity and complexity has a particular discipline in repeating elements of all around.

Type 2-Except elements such as ramps and stairs of the basement the rest arranged with perfect order, but the simplicity of façade can't be considered absolute.

Type 3-The building doesn't have order and the chaos is apparent and despite the simplicity of component elements, except in overall glance looks complicated.

Type 4-Order and simplicity are at its peak.

\section{THE INDIVIDUATION OF AXIS محر بتذي ....}

Type 1-By rotating around the building it is perceived, that all of its eight sides have symmetry about the vertical axis and its individuation is high level.

Type 2-The building to the vertical axis has symmetry and totally a considerable individuation.

Type 3-Parts of the facade have symmetry about the vertical axis separately, but in total, the building has no axis

Type 4- The building to the vertical axis is symmetrical; and individuation in it assessed average.

\section{GLORY OF SCALE}

Type 1-The height of building has out it from proportion with human scale and gave a certain glory to it.

Type 2-Short-height of entrance door to the building indicates the glory of its scale.

Type 3- The dimensions in each stratum is proportional to the human scale. However, the building compared other buildings have significant glory.

Type 4-Due to the integration of building the man sees himself small in it, but not weak.

\section{SHADOW AND LIGHT (PENUMBRA)}

Type 1- The shadow of sides (angles) with very gentle angle on each side, plus rotating shade within the building which is also visible from the outside contributes in more diversity.

Type 2-The main facade direction towards the northwest, minimizes the contribution of light and shadow, but the rotation of forehead's shadow on the body in the afternoon can't be ignored.

Type 3- Basically due to the curvature of the building and the frequent surface differences the shadow and light (Penumbra) show should be at its peak. But due south direction and direct radiation in many hours it has been moderated.

Type 4-The main facade is in the north and does not see a remarkable light in itself. Brief early hours of light in the projection of building and in the entrance converted to shadow and light (Penumbra).

\section{ANALYTICAL DIAGRAMS OF TRADITIONAL AND CONTEMPORARY BUILDINGS IN A AND B INDICES}

\section{(Chart 1) Happiness and luxury index for traditional buildings}




\section{Traditional Buildingąpaport charts and luxury} happiness index

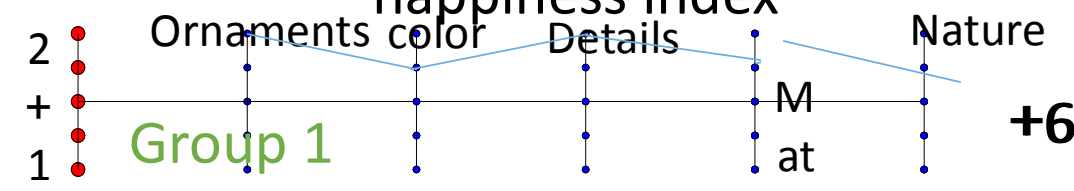

Imamzadeh Helaltibn Ali (AS)

er

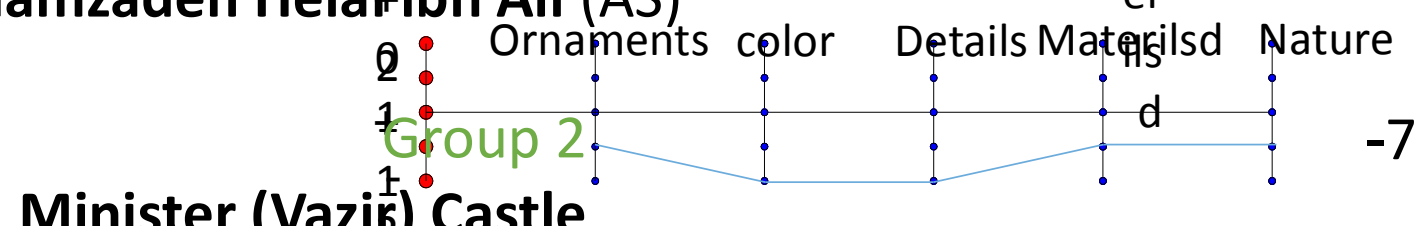

Minister (Vaziki ) Castle

āb ąghbār or water rzeservoir

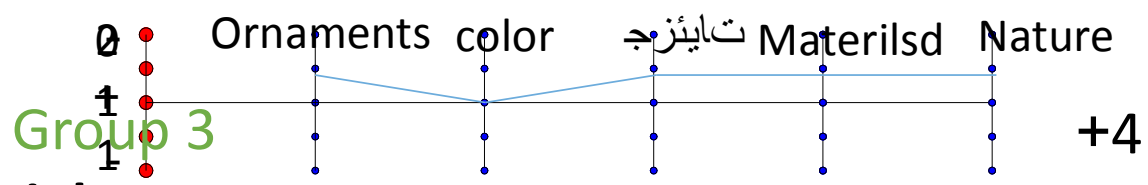

Marnjab Inn

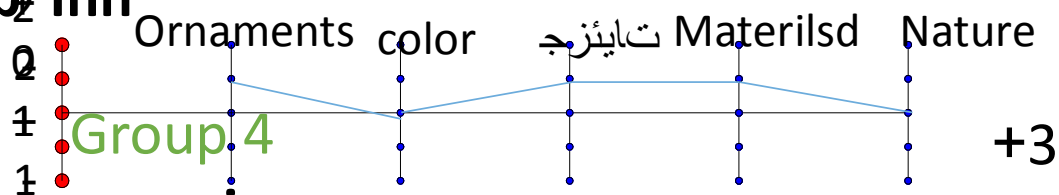

$\theta$

1

2

(Chart 2) Happiness and luxury index for contemporary buildings 
Tomb of Suleiman Sạbahi Bidgoli

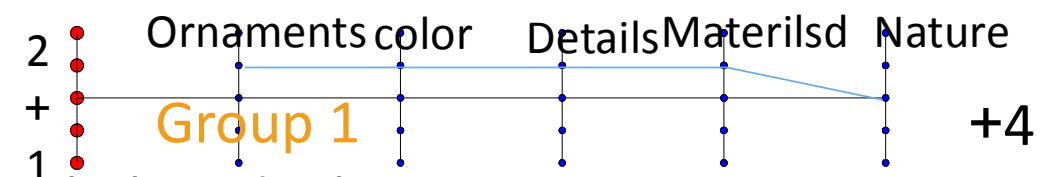
0 : Ornaments color DetailsMaterilsd Nature

Governor bruilding
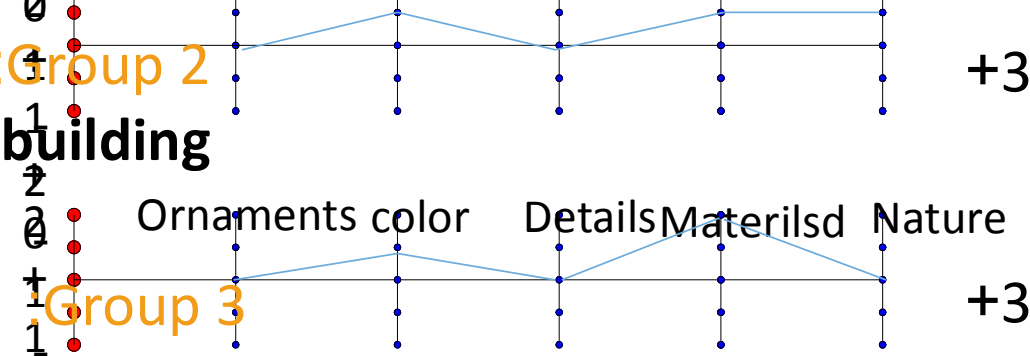

Shaban tradefomplex

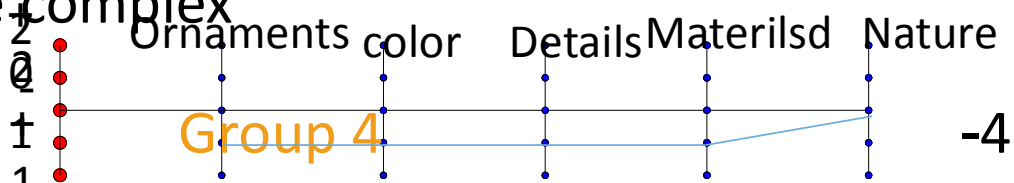

\section{Department of Telecommunications}

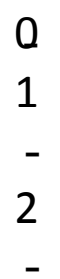

(Chart 3) Readability and meaning index for traditional buildings 


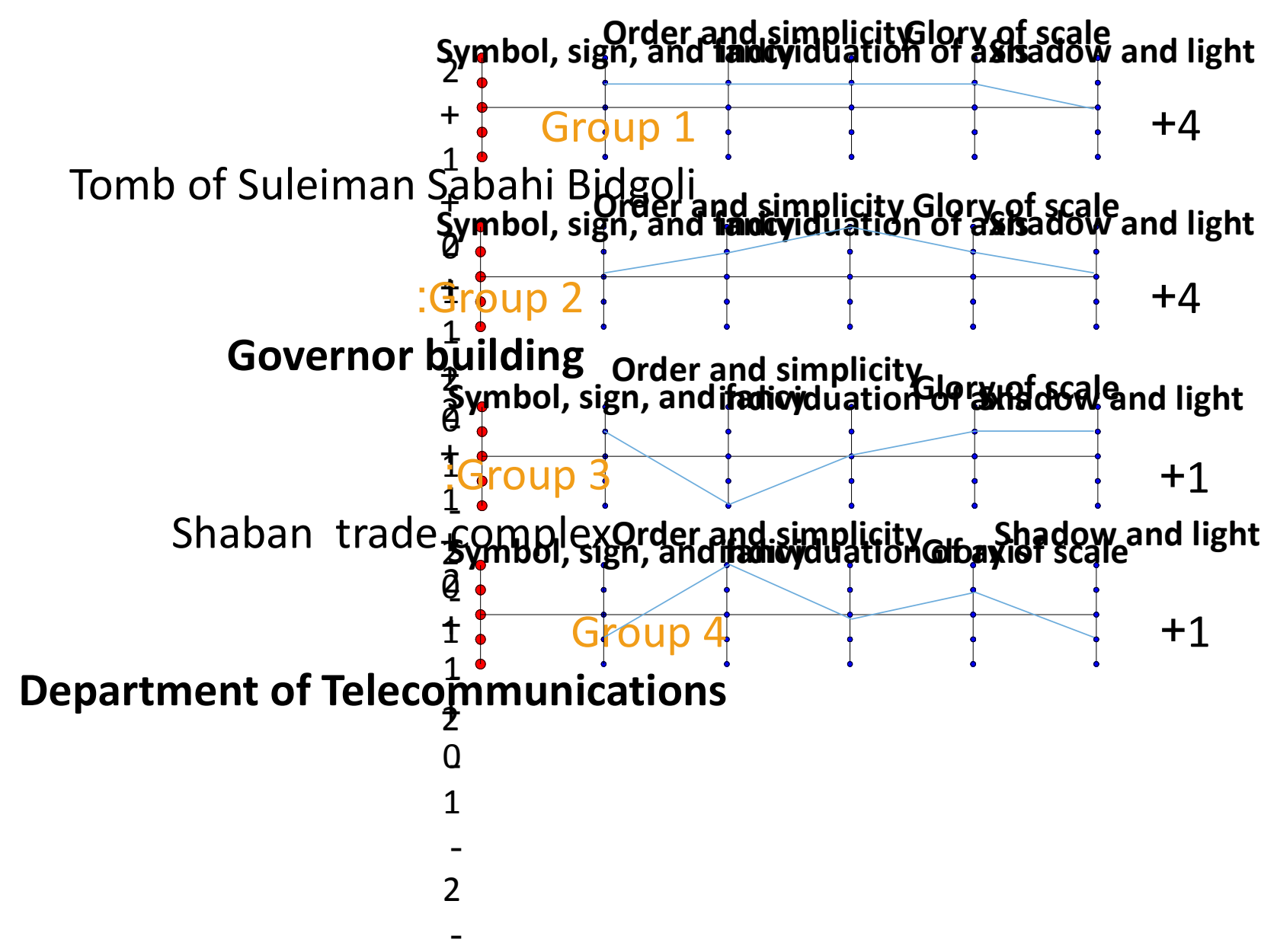

(Chart 4) Readability and meaning index for contemporary buildings 


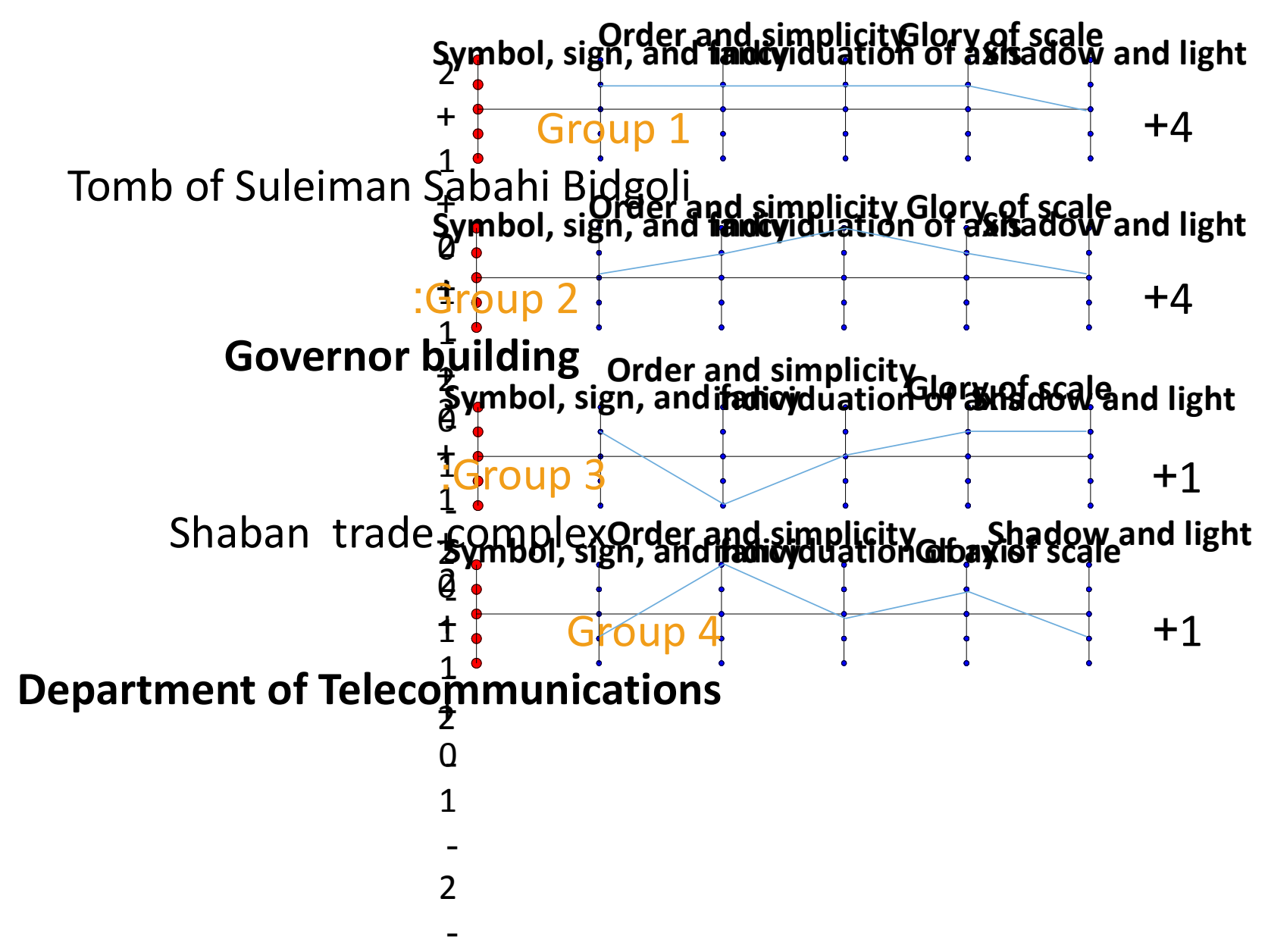

(Chart 5) The comparison of happiness and luxury index for traditional and contemporary buildings

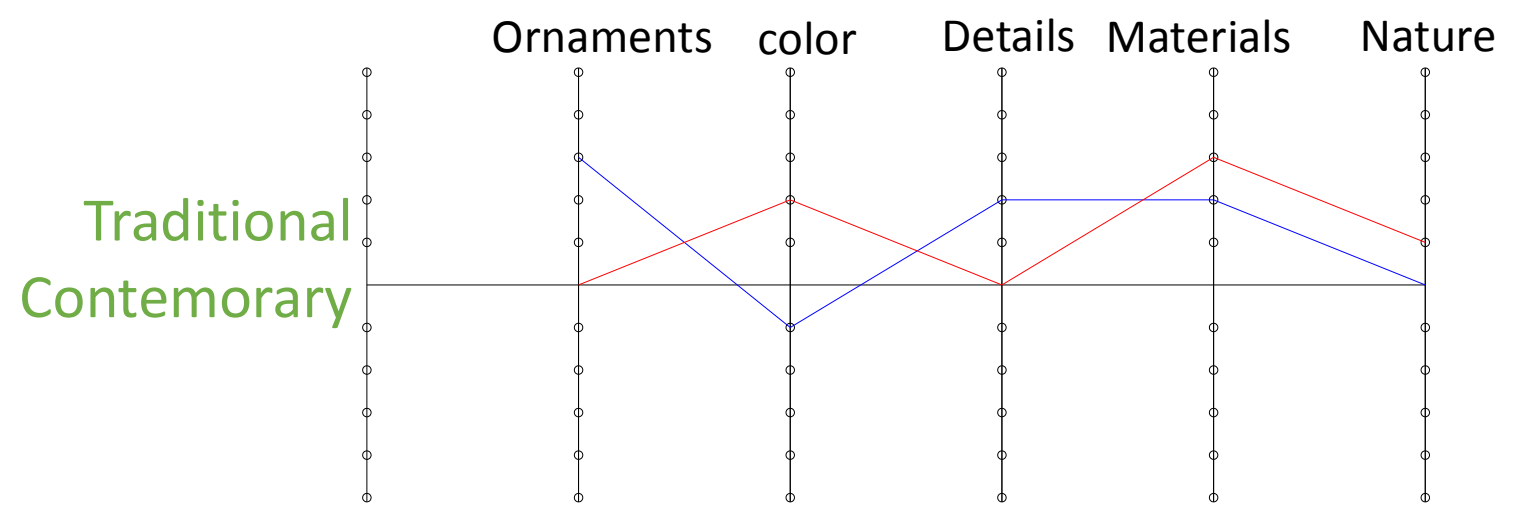

(Chart 6) The comparison of Readability and meaning index for traditional and contemporary buildings 


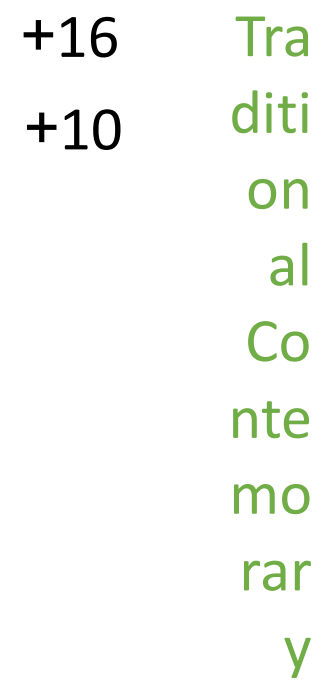

\section{Order and simplicity Symbol, sign, and fariadividuation of axis Glory of}

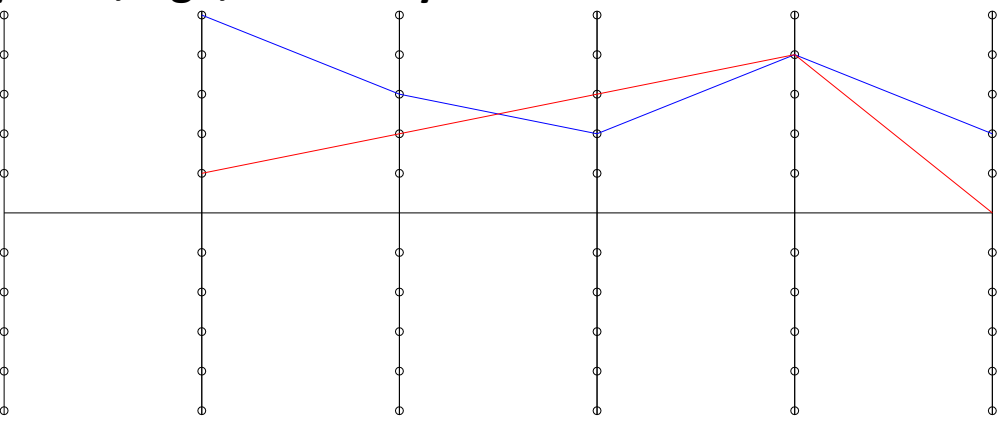

\section{RESULTS}

The order of types in the index of A (happiness and luxury), according to this study: $\mathbf{2}<\mathbf{4}<\mathbf{3}<\mathbf{1}$

The order of types in the index of A (readability and meaning), according to this study: $\mathbf{4}<\mathbf{3}<\mathbf{2}<\mathbf{1}$

Table 1 The comparison of status (position) of tomb of the Holy Helal Ibn Ali (AS) in index A: (happiness and luxury)

\begin{tabular}{|c|c|c|c|c|}
\hline $2 a<$ & $4 b<$ & $4 a, 2 b, 3 b<$ & $3 a, 1 b<$ & $1 \mathbf{a}$ \\
\hline $\begin{array}{l}\text { Castle of } \\
\text { minister }\end{array}$ & Telecommunications & $\begin{array}{c}\text { Commercial } \\
\text { Building } \\
\text { Governor } \\
\text { building } \\
\text { Ab anbar (water } \\
\text { reservoir) }\end{array}$ & $\begin{array}{c}\text { Tomb of } \\
\text { Suleiman } \\
\text { Sabahi, } \\
\text { Maranjab } \\
\text { Inn }\end{array}$ & $\begin{array}{l}\text { Monument of } \\
\text { Hilal bin Ali } \\
\text { (AS) }\end{array}$ \\
\hline 7 & 4 & +3 & +4 & +6 \\
\hline
\end{tabular}

Table 2 The comparison of status (position) of tomb of the Holy Helal Ibn Ali (AS) in index B: (readability and meaning)

\begin{tabular}{|c|c|c|}
\hline > & > $1 b$ و $3 a b$ و $2 a$ & $1 \mathbf{a}$ \\
\hline $\begin{array}{c}\text { Tomb of Suleiman } \\
\text { Sabahi, } \\
\text { Governor building } \\
\text { Commercial Building }\end{array}$ & $\begin{array}{c}\text { Maranjab Inn } \\
\text { Castle of minister } \\
\text { Tomb of Suleiman } \\
\text { Sabahi, }\end{array}$ & $\begin{array}{l}\text { Monument of } \\
\text { Hilal bin Ali } \\
\text { (AS) }\end{array}$ \\
\hline
\end{tabular}




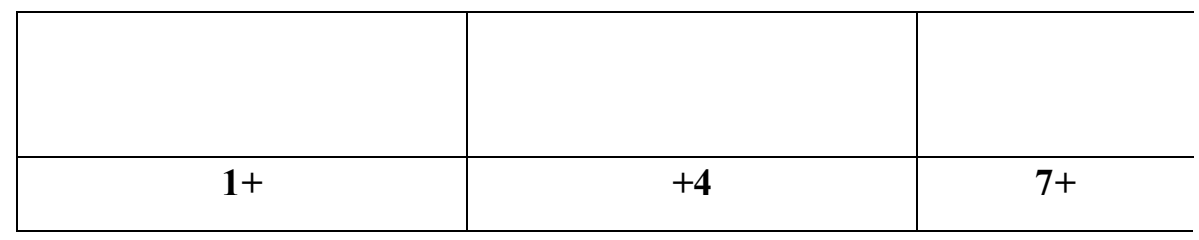

d. The results of the comparison charts of happiness and luxury of traditional buildings, suggests the superiority of six points of Helal bin Ali (AS) tomb shrine compared with the average of other three buildings; which this positive difference, compared to the average contemporary buildings has been four and four and a half, respectively.

\section{CONCLUSION}

Based on comparative graphs and tables (charts 1 to 6 and Tables 1 and 2 of the study), analysis suggests the building appearance of the mausoleum of Imamzadeh Helal Ibn Ali (AS) with significant concessions to different personality (character) types of traditional and contemporary buildings, has excellence (superiority) in both $<<$ happiness and luxury $>>$ and $<<$ readability and meaning $>>$. This conclusion represents the richness of architectural and means, on the one hand the building maintained its dignity and grandeur at the highest level and the same time, pilgrims and bystanders with presence in the doorstep atmosphere, have the feeling of joy and free soul. Thus, the architect architectures have done their mission properly.

\section{ACKNOWLEDGEMENT}

Hereby we acknowledge to all the institutions and those who the writing of this article and doing this research indebted to their invaluable assistance including: Architecture professors of Kashan University, Board of Trustees of Imamazadeh Helal Ibn Ali (AS), Department of Cultural Heritage, Handicrafts and tourism of Aran and Bidgol and technical training and professional office staff of Aran and Bidgol.

\section{SUBSCRIPTS}

1- Alain de Botton

2-amus rapaport

3-(N, k, Rappaport, 2005)

4-(N, k, de Botton

, 2005)

5-(N, k, Pakzad, 2012)

\section{REFERENCES}

1-Rapoport, Amos (2005-M), culture, architecture and design, Translated by Maria Barzegar and Majid Yusuf Nyapasha (2012). Sheflyn publication.

2-Dv de Botton, Allian (2005), Architecture of Happiness, translated by Parvin Aghayee, (2010). Sahbay-e Danesh publication.

3-Pakzad, Jahanshah and Bozorg, Hamideh (2012), ABC of psychology for designers, Arman-Shahr (utopia) publication. 